\title{
ANALISIS KINERJA PELAYANAN PRASARANA PELABUHAN FERI BAJOE KABUPATEN BONE
}

\author{
Muhammad Natsir Husain ${ }^{1}$, Adithya Yudistira ${ }^{2}$ \\ 1,2 Program Studi Arsitektur, Fakultas Teknik Universitas Muslim Indonesia
}

\begin{abstract}
Abstrak
Penelitian ini bertujuan mengetahui bagaimana kinerja pelayanan prasarana pelabuhan ditinjau dari persepsi penumpang pada pelabuhan Feri Bajoe, dan bagaiamana prediksi pertumbuhan penumpang sepuluh tahun kedepan, apakah masih sesuai atau seimbang dengan fasilitas prasarana pelabuhan yang ada. Penelitian dilakukan pada pelabuhan Feri Bajoe Kabupaten Bone. Data dikumpulkan melalui pengamatan langsung. Data dianalisis dengan menggunakan deskriptif kuantitatif. Hasil penelitian menunjukkan bahwa penilaian kinerja prasarana Pelabuhan Feri Bajoe yang meliputi variabel dermaga, parkir kendaraan tunggu, dan ruang tunggu secara total menurut persepsi penumpang berada pada katagori kurang baik dengan total skor 4.469. Oleh sebab itu jarak capai, memisahkan jalur jalan bagi penumpang tidak berkendaraan dengan penumpang berkendaraan, menyiapkan moda angkutan gratis bagi penumpang masuk ke terminal pelabuhan, menyiapkan sarana pendukung khusus pada parkir kendaraan tunggu, penentun pola parkir yang jelas, dan menyiapkan sarana tempat duduk pada ruang tunggu penumpang.
\end{abstract}

Kata Kunci: Prasarana pelabuhan

\begin{abstract}
This aims of the research were to investigate (1) the service performance of port infrastructures according to passengers' perception in Bajoe Ferry Port, (2) the passenger growth forecast within the next ten years, to determine wether it is still appropriate for the existing port infrastructure facilities. The study was conducted at the Ferry Port Bajoe of Bone. Data was collected with direct observation and was analyzed with qualitative and quantitative descriptive method. The results of the research indicated that the service performance of Ferry port, Bajoe Facilities, which includes variables such as docks, vehicle parking and waiting rooms according to the passenngers' perception were not good with a total score 4469. Therefore there was a need to redesign the dock's accessibility to shorten the distance, to separate lanes for driving passengers and non-driving passengers, to set up the free mode of transport for passengers to enter the port terminal, and to set up special support facilities at the parking lot waiting area, and to determine the parking patterns with clear parking markers, and accomodate seating facilities in the passengers' waiting rooms.
\end{abstract}

Keywords: infrastructure, Port infrastructure

\section{PENDAHULUAN}

Indonesia merupakan Negara terbesar dimana 63 $\%$ wilayah teritorialnya berupa perairan. Indonesia juga memiliki pantai terpanjang didunia yaitu $81.000 \mathrm{~km}, \quad$ (Gultom,Elfrida,2007). Sebagai kepulauan terbesar, sektor maritim perlu dikembangkan dengan baik untuk membantu Negara dan Masyarakat mencapai tujuan ekonomi, sosial, politik dan keamanan. Negeri ini memiliki hasil bumi, hasil laut, hasil tambang dan hasil industri yang sangat potensial. Kekayaan tersebut dapat diolah untuk memenuhi kebutuhan dalam negeri maupun diekspor keluar negeri. Sejalan dengan kondisi ini mobilitas penduduk dengan berbagai aktifitas membutuhkan sarana dan prasarana transportasi, baik darat, udara maupun laut, untuk mengangkut hasil bumi/ pangan, sandang/ industri, dari satu pulau kepulau lain, atau suatu daratan ke ujung daratan lain dengan sarana transportasi.
Faktor ketepatan pemberangkatan, kenyamanan dan keamanan penumpang, dapat dipengaruhi oleh, kondisi area depan dermaga saat antrian kendaraan tidak steril dari kendaraan lain. Demikian juga pada jalur sirkulasi penumpang yang menyatu dengan jalur kendaraan tentunya berpengaruh pada perlambatan pergerakan kendaraan, keamanan dan kenyamanan bagi pejalan kaki. Faktor lain adalah pola parkir kendaraan/ lay out sirkulasi yang tidak jelas dari parkir tunggu kendaraan menuju dermaga. Kondisi lainnya pada jalur sirkulasi penumpang adalah ketidak nyamanan dilewati karena tidak beratap, sebaiknya diperlukan Gang Way yang melindungi penumpang dari terpaan panas Matahari dan hujan. berikut:

Tujuan penelitian yang ingin dicapai sebagai

1. Memberi gambaran kinerja pelayanan fasilitas prasarana ditinjau dari tingkat kepuasan penumpang (tidak berkendaraan dan 
berkendaraan) pada fasilitas-fasilitas utama pelabuhan Feri Bajoe:

a. Area Dermaga, dengan melihat pada indikator ketepatan pemberangkatan penumpang.

b. Lapangan Parkir Kendaraan Tunggu dengan indikator kenyamanan dan keamanan, sedang pada fasilitas;

c. Ruang Tunggu penumpang pada terminal, dengan indikator kenyamanan dan keamanan penumpang .

2. Mengetahui pertumbuhan penumpang (tidak berkendaraan dan penumpang berkendaraan) sepuluh tahun kedepan tahun 2020, kemudian memberi analisa keseimbangan antara penumpang dengan fasilitas prasarana pelabuhan.

\section{ISI PENELITIAN}

\section{A. JENIS PENELITIAN}

Jenis penelitian yang digunakan adalah penelitian yang sifatnya deskriptif kualitatif yaitu memberikan gambaran kinerja pelayanan prasarana tanpa melakukan uji Hipotesis. Penelitian dilakukan dengan survey dan pengamatan langsung di lapangan untuk menilai kinerja pelayanan prasarana/ fasilitas pokok pelabuhan ditinjau dari tingkat kepuasan penumpang tidak berkendaraan, penumpang berkendaraan pada pelabuhan penyeberangan Feri Bajoe Kabupaten Bone Sulawesi Selatan.

Penelitian dilakukan pada fasilitas Dermaga, Fasilitas Parkir Kendaraan Tunggu, ruang tunggu penumpang dan peramalan pertumbuhan penumpang tdak berkendaraan, penumpang berkendaraan dan kendaraan barang. Pada pelaksanaannya juga terbagi dalam tiga tahap yaitu pengumpulan data primer dan data skunder, kemudian tahap analisa dan tahap perumusan kesimpulan pada tingkat kepuasaan penumpang terhadap pelayanan dermaga, parkir tunggu kendaraan dan Ruang tunggu. Pada pengolahan data menggunakan analisis regresi ordinal pada data kualitatif yang akan menggambarkan tingkat kepuasan penumpang.

\section{B. TEMPAT DAN WAKTU PENELITIAN}

Lokasi penelitian di Prop. Sulawesi Selatan, Ibukota kabupaten Bone Kecamatan Tanete Riattang Timur yaitu pada Pelabuhan Feri Bajoe. Obyek penelitian pada area bagian dalam pelabuhan dimana Fasilitas Pokok berada dan pengelolaannya ada pada PT .ASDP. Indonesia Feri Bajoe.

\section{TEKNIK PENGUMPULAN DAN SUMBER DATA}

Untuk memperoleh hasil yang maksimal dalam penelitian ini, maka ditempuh proses sebagai berikut;

1. Teknik pengumpulan data

a. Wawancara
Melakukan dialog secara langsung pada responden terpilih dalam menghimpun data yang relepan dan akurat, baik pada pengelola pelabuhan, pengusaha kapal Feri, dan penumpang,

b. Metode observasi

Data yang diperoleh dengan pengamatan langsung dilapangan, digunakan sebagai tambahan informasi, serta pembanding dari data yang diperoleh dari wawancara dan dari data skunder. Data yang dibutuhkan adalah fasilitas-fasilitas pokok pelabuhan utamanya pada Dermaga, dan Lapangan parkir (tunggu) kendaraan untuk naik ke kapal sebagai sasaran penelitian.

c. Angket;

Melakukan pegumpulan data dengan cara menyajikan daftar pertanyaan secara tertulis (tertutup) terhadap responden untuk memperoleh data persepsi penumpang terhadap penggunaan parkir tunggu kendaraan dan terhadap ketersediaan sarana pendukung, kenyamanan dan keamanan pada fasilitas Parkir Tunggu Kendaraan.

d. Dokumentasi.

Merekam kondisi fisik pelabuhan secara visual dalam bentuk gambar peta site dan foto-foto sesuai kebutuhan penelitian.

2. Sumber Data

a. Data primer

Adalah data yang diperoleh melalui pengamatan langsung dilapangan, teknik ini dilakukan untuk memperoleh kondisi dan gambaran umum lokasi penelitian secara langsung dari Fasilitas pokok pelabuhan Feri Bajoe seperti;

b. Data skunder

Adalah data yang diperoleh melalui instansi terkait berupa data yang sudah ada sebelumnya, untuk data Dermaga diperlukan al;

1) Jumlah penumpang, kendaraan, kendaraan dengan barang,

2) Jumlah embarkasih dan debarkasi kapal dan jumlah ship pemberangkatan.

3) Gambar Peta lokasi, Peta site dan fasilitas-fasilitas yang terdapat di pelabuhan Feri Bajoe.

4) Karakteristik kapal yang berlabuh Sedang data skunder untuk lapangan parkir kendaraan tunggu sejalan dengan data Dermaga pelabuhan disamping studi kepustakaan, yang membedakan pada jenis data sesuai skopnya sebagai area parkir :

1) Data untuk Fungsi ruang parkir maka dibutuhkan data Jumlah kendaraan Parkir, lama parkir, kapasitas parkir, pergantian parkir, 
2) untuk variabel kenyamanan pengguna parkir dibutuhkan data ketersediaan sarana-sarana pendukung kenyamanan seperti tempat tunggu/istirahat sopir, ruang ibadah, pengambilan uang/ATM, Toilet, masalah kebersihan, daya tarik parkir, kemudahan parkir dan signage/papan info, petunjuk parkir.

3) Untuk variabel Keamanan, seperti adanya petugas keamanan, parkir dan tersedianya sarana keamanan seperti fire Hydran, tabung pemadam kebakaran, alarm untuk kondisi darurat/CCTV dan pencahayaan yang cukup pada area parkir.

4) Suber Data tersebut diatas dapat diperoleh dari pengelola pelabuhan, pengusaha kapal, dan responden.

c. Data kepustakaan

Dilakukan dengan menelusuri berbagai dokumen dan literature yang berkaitan dengan masalah penelitian.

\section{TEKNIK ANALISA DATA}

Teknik analisa data dalam penelitian ini terhadap rumusan masalah kinerja Pelayanan Prasarana yaitu Fasilitas Dermaga dilaksanakan dengan pendekatan kuantitatif, sedang Fasilitas Parkir Kendaraan Tunggu dengan pendekatan kualitatif.

\section{E. HASIL DAN PEMBAHASAN}

\section{Analisis Kinerja Fasilitas Prasarana} Pelabuhan

Kinerja pelayanan fasilitas pelabuhan adalah kemampuan kerja fasilitas fisik pelabuhan dalam melayani suatu aktifitas pergerakan penumpang tidak berkendaraan dan berkendaraan dalam memperoleh ketepatan pemberangkatan, kenyamanan dan keamanan dalam suatu priode waktu.

Dermaga merupakan fasilitas yang utama dari suatu proses pemberangkatan/ penyeberangan penumpang untuk itu perlu mengukur kinerja dengan sub variabel ketepatan pemberangkatan dimana sebagai indikator dalam menilai pelayanan , dipengaruhi dari beberapa aspek seperti: akses ke dermaga, kondisi, mekanisme dermaga dan kesiapan jalur sirkulasi ke dermaga.

Indikator Ketepatan pemberangkatan dianalisa dari jawaban responden dari kuisioner yang dibagikan pada 90 responden/ penumpang yang akan melakukan perjalanan dan pernah melakukan perjalanan melalui pelabuhan Feri Bajoe minimal 3 X. Setiap jawaban akan di beri nilai skala mulai dari 1 ;sebagai kondisi sangat tidak baik, 2 kurang baik, 3 sebagai Baik dan 4 adalah kondisi sangat baik.

\section{Indikator Ketepatan Pemberangkatan pada area dermaga \\ Ketepatan pemberangkatan sebagai indikator} dalam menilai pelayanan area Dermaga, dipengaruhi dari beberapa faktor seperti: akses ke dermaga, kondisi, mekanisme dermaga dan kesiapan jalur sirkulasi ke dermaga.

a. Akses dari pintu gerbang pelabuhan ke dermaga.

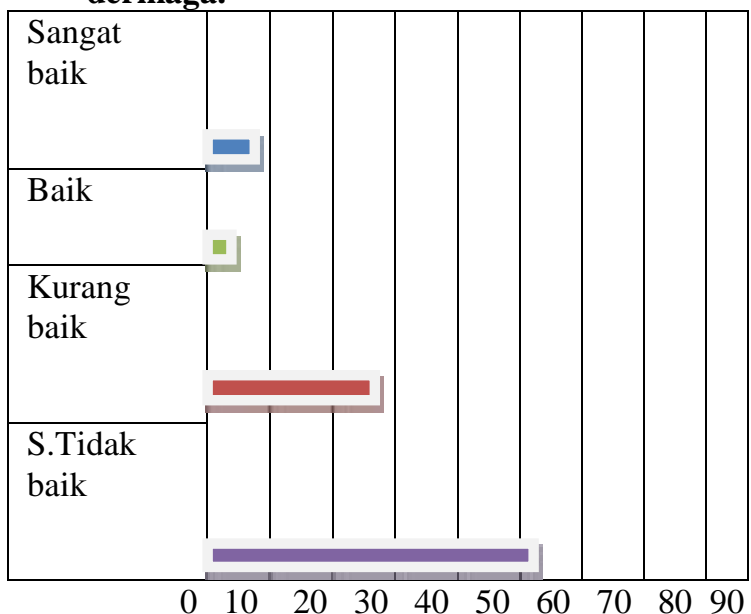

Gambar 1. Grafik Histogram jarak capai dari pintu gerbang pelabuhan ke dermaga

Dari gambar Histogram diatas terlihat bahwa; $57 \%$ menyatakan tidak baik ( sangat jauh), $31 \%$ menyatakan kurang baik (jauh), $3 \%$ baik (dekat) dan 9\% sangat baik(sangat dekat). Hasil ini menunjukkan bahwa responden dominan menilai jarak capai dari pintu gerbang ke dermaga sangat jauh dan tidak disediakan alat transportasi gratis oleh pihak pelabuhan sebagai standar pelayanan.

b. Akses dari pintu gerbang ke terminal penumpang/ ruang tunggu penumpang.

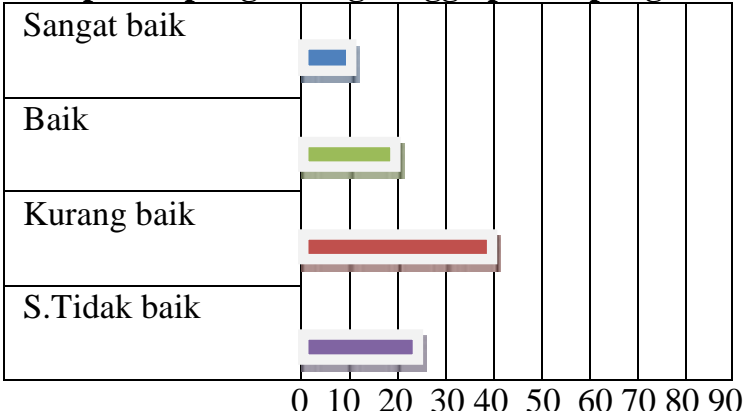

Gambar 2. Histogram Akses dari pintu masuk pelabuhan ke terminal pelayanan penumpang/ ruang tunggu.

gambar diatas terlihat bahwa $43 \%$ menyatakan kurang baik (dekat), $21 \%$ menyatakan cukup baik, $10 \%$ sangat baik dan $26 \%$ menyatakan tidak baik. Grafik ini menunjukkan responden dominan menilai jarak capai dari pintu gerbang ke tempat parkir tunggu dan ke dermaga kurang dekat. 
c. Akses dari ruang tunggu penumpang/terminal ke dermaga;

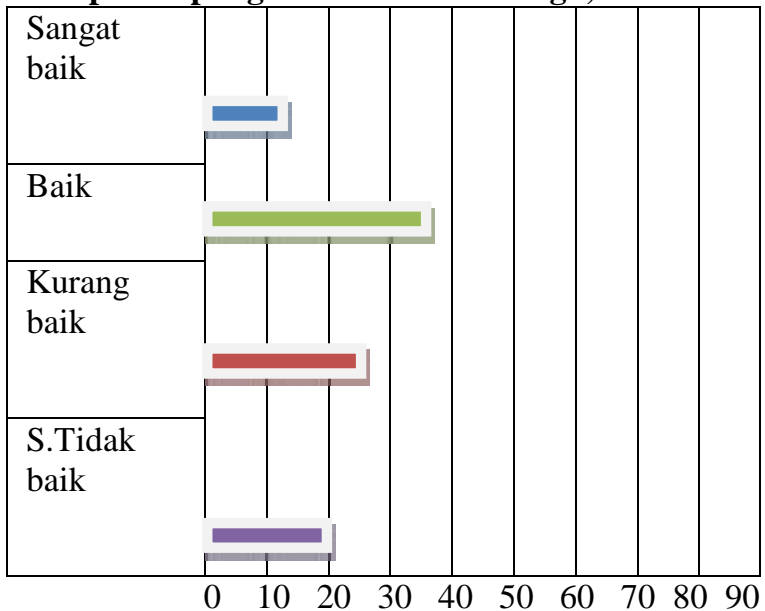

Gambar 3. Histogram jarak capai dari ruang tunggu penumpang ke dermaga

Gambar Histogram diatas menunjukkan bahwa $12 \%$ menyatakan sangat baik/ sangat dekat, $39 \%$ menyatakan baik (dekat), $27 \%$ menyatakan kurang baik, $22 \%$ menyatakan tidak baik. Hasil ini menunjukkan jarak capai dari ruang tunggu penumpang ke dermaga cukup dekat.

\section{d. Kondisi fisik dan mekanisme dermaga}

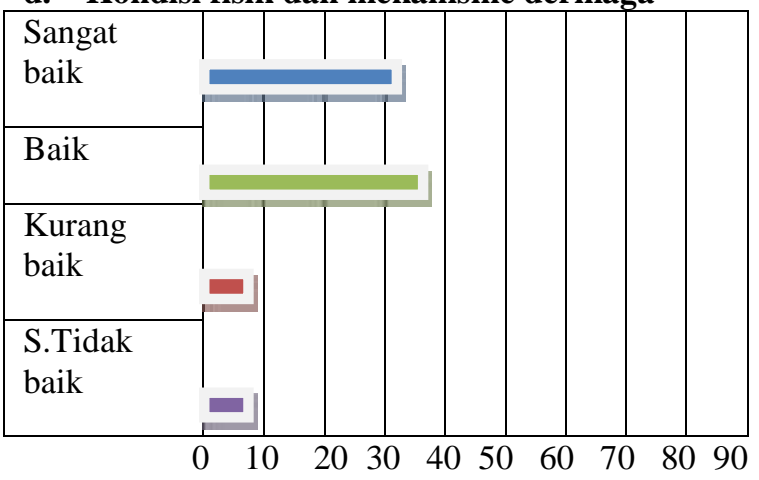

Gambar 4. Kondisi dan mekanisme dermaga

Dari gambar diatas terlihat bahwa $52 \%$ menyatakan baik, $33 \%$ menyatakan sangat baik, 8 $\%$ menyatakan kurang baik $7 \%$ menyatakan tidak baik. Hal ini menunjukkan konidisi dan mekanisme dermaga cukup baik.

\section{e. Jalur sirkulasi kedermaga}

\begin{tabular}{|l|l|l|l|l|l|l|}
\hline $\begin{array}{l}\text { Sangat } \\
\text { baik }\end{array}$ & & & & & & \\
\end{tabular}

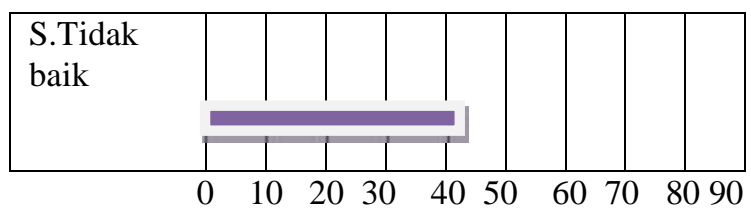

Gambar 5. kondisi jalur sirkulasi ke dermaga

Dari gambar diatas dilihat bahwa $58 \%$ menyatakan tidak baik, $26 \%$ menyatakan kurang baik, $8 \%$ baik, $8 \%$ sangat baik. Kondisi ini dipengaruhi oleh jalur sirkulasi ke dermaga tidak steril dari kendaraan pengantar yang memasuki area dermaga. Hasil diatas menggambarkan bahwa system satu jalur sirkulasi yang menyebabkan bercampurnya pejalan kaki, kendaraan penumpang dan kendaraan barang/ truk sangat menghambat pergerakan penumpang ke dermaga

\section{Kenyamanan Penumpang pada Parkir Kendaraan Tunggu}

Tingkat kenyamanan penumpang pada parkir Kendaraan Tunggu ditinjau dari enam variabel diantaranya: akses dari dan keruang parkir, Papan informasi Parkir, kemudahan parkir, sarana pendukung, kebersihan dan penataan/penghijauan. Tingkat kenyamanan dianalisa dengan menggunakan kuisioner yang diberikan pada 67 responden yang memasuki areal parkir kendaraan tunggu. Nilai setiap veriabel diurut dari angka 1 adalah kondisi paling tidak baik dan angka 4 adalah kondisi yang sangat baik.

a. Akses dari ruang parkir tunggu ke dermaga.

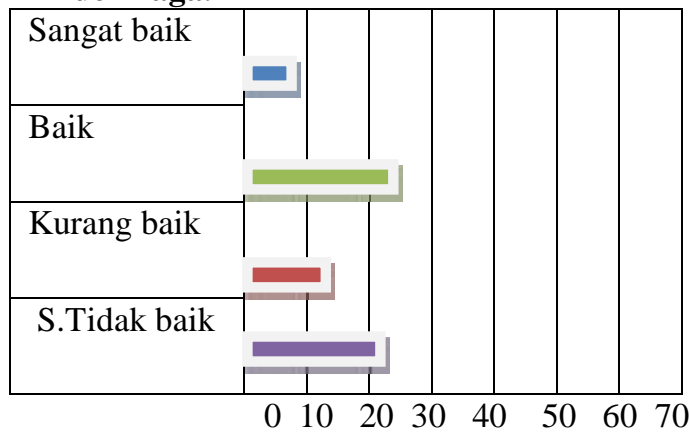

Gambar 6. akses dari ruang parkir tunggu ke dermaga

Dari gambar Histogram diatas terlihat bahwa $39 \%$ menyatakan baik, $9 \%$ menyatakan sangat baik, $21 \%$ kurang baik dan $31 \%$ menilai sangat tidak baik. Hasil diatas menunjukkan responden member penilaian agak seimbang, bahwa jarak capai dari tempat parkir tunggu ke dermaga cukup dekat. 
b. Papan informasi/petunjuk parkir

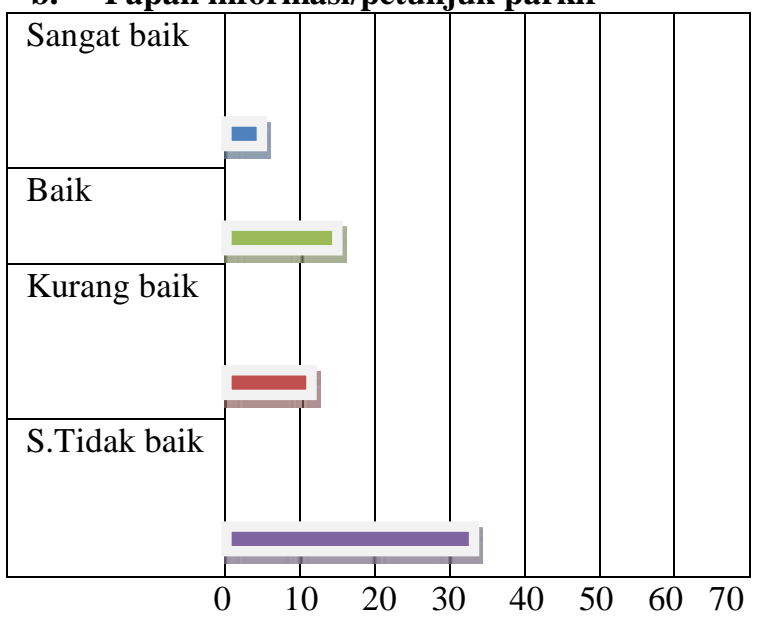

Gambar 7. papan informasi, petunjuk arah dan marka parkir.

Dari gambar diatas terlihat bahwa $52 \%$ responden menyatakan tidak baik, $17 \%$ menyatakan kurang baik, $25 \%$ menyatakan baik, dan $6 \%$ responden menyatakan sangat baik. Kondisi ini menunjukkan papan informasi, penunjuk arah dan marka jalan/parkir pada area parkir sangat minim.

\section{c. Kemudahan Parkir}

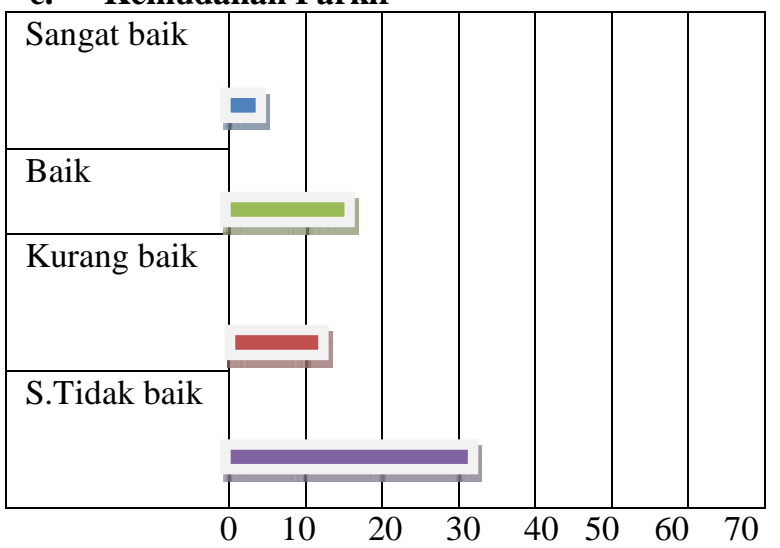

Gambar 8. Kemudahan parkir.

Gambar diatas menjelaskan bahwa $57 \%$ responden menyatakan tidak baik, $15 \%$ menyatakan kurang baik, $22 \%$ menilai baik dan $6 \%$ menilai sangat baik. Kondisi parkir semrawut, hal ini dipengaruhi tidak adanya petugas parkir, papan pengarah parkir, marka parkir yang menjelaskan pola parkir yang digunakan, apakah parkir paralel atau parkir menyudut.

\section{d. Sarana Pendukung pada area parkir; Tempat istrirahat pengendara dan penumpang, telephon umum, Atm, dan mushala.}

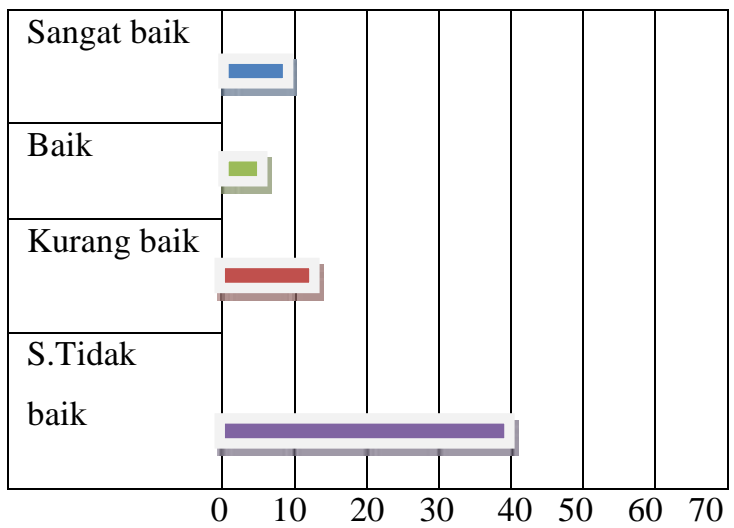

Gambar 9. Sarana pendukung area parkir

Dari gambar Histogram diatas terlihat bahwa $58 \%$ menyatakan tidak baik, , $18 \%$ menyatakan kurang baik, $11 \%$ baik, dan $13 \%$ menyatakan sangat baik.penilaian ini didasari oleh tidak tersedianya sarana pendukung diatas pada tempat parkir tunggu

e. Penataan landsekap/ penghijauan

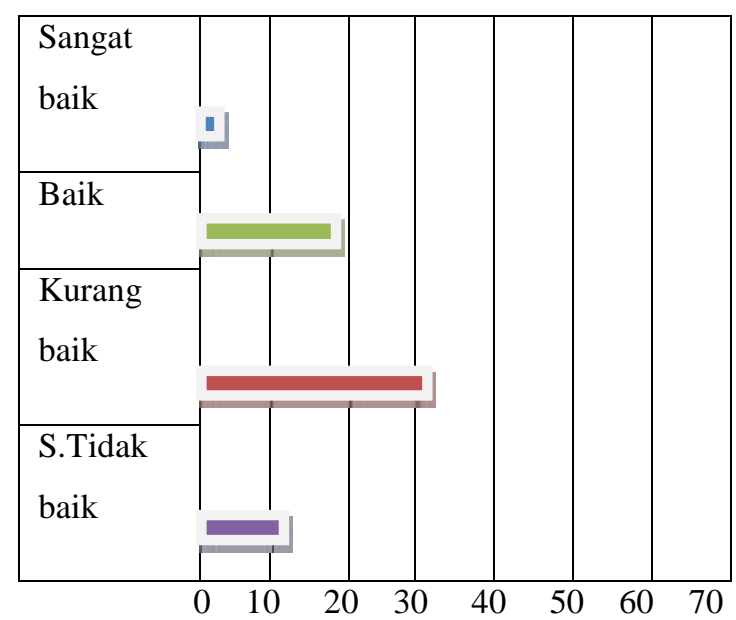

Gambar 10. kondisi penataan landsekap dan penghijauan.

Dari gambar diatas terlihat bahwa $48 \%$ menyatakan kurang baik, $16 \%$ menyatakan tidak baik, $28 \%$ menyatakan cukup baik dan $8 \%$ sangat baik. Penilaian responden bisa dipengaruhi kondisi area parkir hanya diberi pohon pelindung secukupnya tanpa penataan taman pada area pedestrian, dan tidak adanya sarana ruang duduk/istirahat.

\section{Keamanan Penumpang pada Parkir Kendaraan Tunggu.}

Tingkat keamanan penumpang pada parkir Kendaraan Tunggu ditinjau dari 3 faktor diantaranya: tersedianya sarana keamanan yang memadai.

Tingkat keamanan dianalisa dengan menggunakan kuisioner yang diberikan pada 67 
responden yang memasuki areal parkir kendaraan tunggu. Nilai setiap veriabel diurut dari angka 1 adalah kondisi paling tidak baik dan angka 4 adalah kondisi yang sangat baik.

\section{a. CCTV sebagai pemantau keamanan dan alat} komunikasi

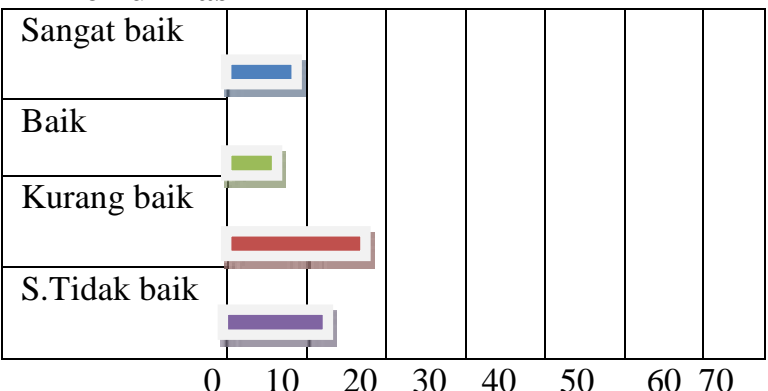

Gambar 11: Histogram kondisi CCTV dan alat komunikasi

Dari gambar Histogram diatas terlihat bahwa $42 \%$ responden menyatakan kurang baik, $18 \%$ menyatakan tidak baik, $27 \%$ menyatakan baik dan $13 \%$ menilai sangat baik. Penilaian ini dipengaruhi oleh tidak tampak adanya petugas berpatroli dan belum adanya CCTV yang memantau area parkir.

\section{b. Pedestrian bagi penumpang dan pengendara}

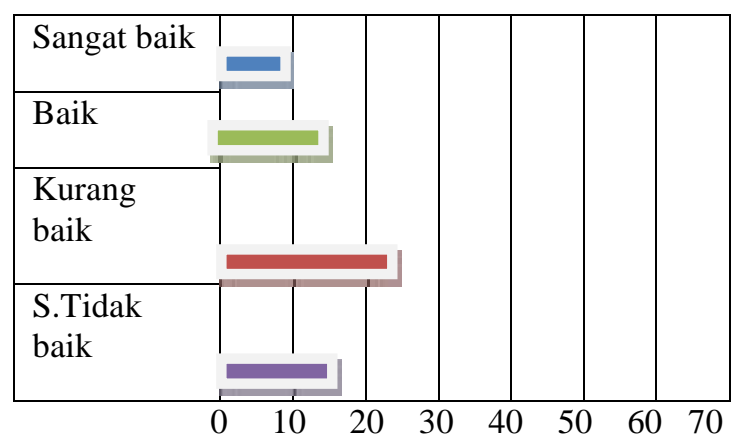

Gambar 12: Penilaian pada Pedestrian

Dari gambar Histogram diatas dilihat bahwa $48 \%$ menyatakan kurang baik, $16 \%$ menyatakan tidak baik, $21 \%$ menilai baik dan $13 \%$ menyatakan sangat baik. Hal ini dipengaruhi kondisi pedestrian yang tidak memenuhi syarat dari segi lebar, penataan dan kelengkapan.

c. Fasilitas kebakaran pada area parkir ( Kran Fire Hydrant, tabung portable)

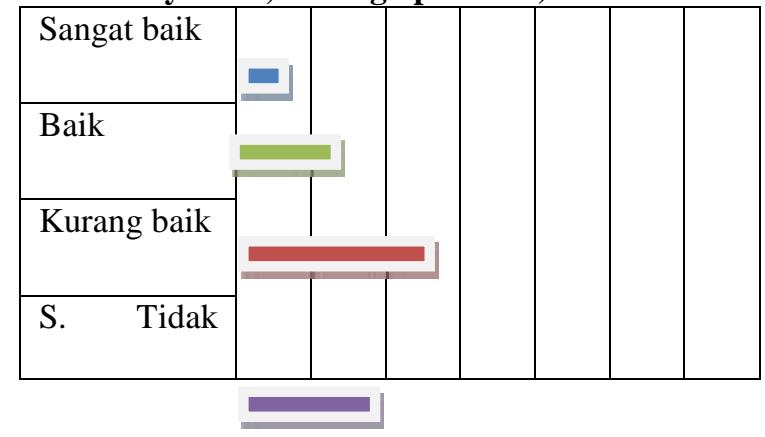

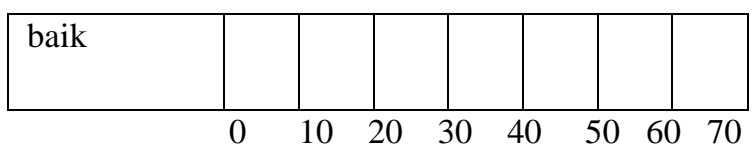

Gambar 13. Histogram sarana pengamanan kebakaran

Dari gambar Histogram diatas terlihat bahwa $40 \%$ menyatakan kurang baik, $28 \%$ menyatakan tidak baik, $20 \%$ cukup baik dan $12 \%$ menyatakan sangat baik. Penilaian rersponden didasari tidak nampaknya sarana tersebut pada area parkir.

d. Pencahayaan/ penerangan dimalam hari

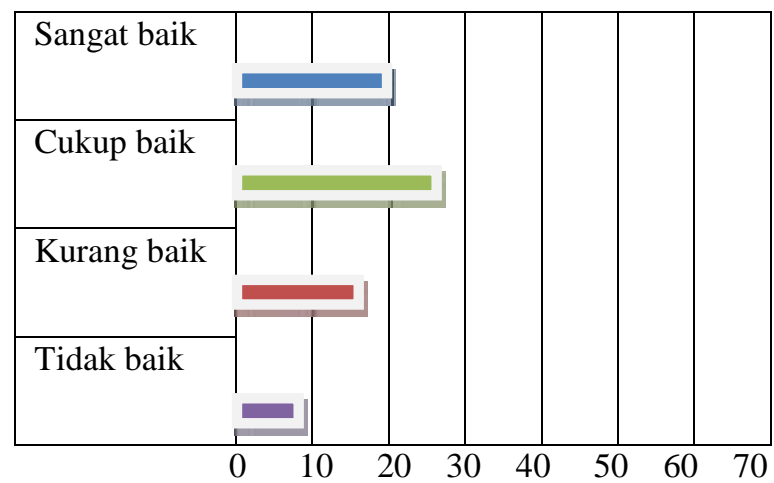

Gambar 14. Penerangan malam hari

Dari gambar Histogram diatas dilihat bahwa $42 \%$ menyatakan cukup baik, $28 \%$ menyatakan sangat baik, $21 \%$ menyatakan kurang baik dan $9 \%$ menyatakan tidak baik. Responden ini didasari kondisi penerangan malam hari cukup baik.

\section{Analisis Kinerja Dermaga}

Analisis kinerja dermaga menunjukkan bahwa secara umum keterlambatan pemberangkatan dari faktor pencapaian dari pintu gerbang pelabuhan kedermaga berada pada katagori tidak dekat (84\%) dengan jumlah Skor 76 yang di pilih 76 orang, demikian juga untuk jarak dari gerbang ke terminal penumpang berada pada tingkat tidak dekat $(71 \%)$ dengan jumlah skor 64 yang dipilih 64 orang. dan untuk kondisi dermaga berada pada tingkat Cukup Baik $(61 \%)$ dengan jumlah skor 65 yang dipilih 55 orang. Pada jalur sirkulasi depan dermaga berada pada tingkat kurang baik $69 \%$ dengan jumlah skor 124 yang dipilih 62 responden. Secara keseluruhan Ketepatan Pemberangkatan berada pada total skor 926 , hasil ini berarti berada pada katagori kurang baik $=787,6-1.125$

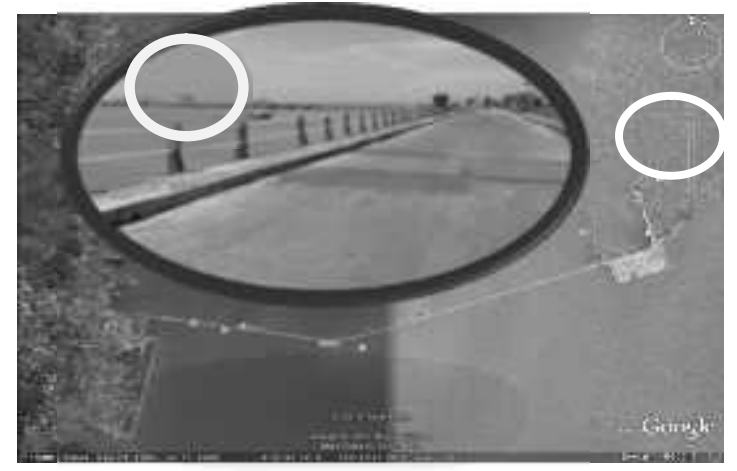


Gambar 15.Kondisi Jarak capai ke dermaga

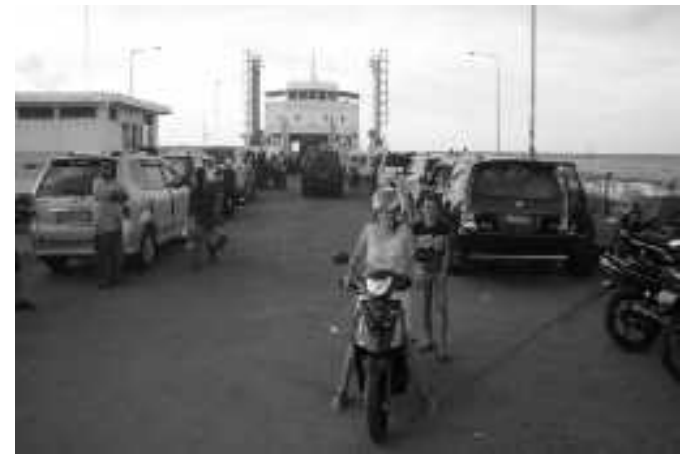

Gambar 16.Kondisi sirkulasi bersama kendaraan dengan PejalanKaki dan tidak steril dari kendaraan pengantar.

\section{Analisis Kinerja Parkir Kendaraan Tunggu}

a. Kenyamanan

Tingkat kenyamanan penumpang pada parkir Kendaraan Tunggu ditinjau dari enam indikator yang berpengaruh yakni: luas/ daya tampung parkir , Papan informasi/ petunjuk arah masuk parkir, kemudahan parkir, kebersihan area parkir, sarana pendukung (tempat istirahat sopir/ pengendara dan penumpang, mushalla, telephon umum, ATM), penataan Landsekap/ penghijauan. Distribusi Frekuensi Persepsi penumpang terhadap Parkir Kendaraan Tunggu dengan indikator Kenyamanan.

Secara umum hasil dari indikator kenyamanan pada parkir kendaraan tunggu yaitu; Sarana pendukung pada area parkir berada pada katagori tidak lengkap ( $74 \%$ ) dengan jumlah skor 67 , dipilih 67 orang responden, untuk penataan lansekap dan penghijauan pohon parkir berada pada katagori Kurang Baik (65 \%) dengan jumlah skor 118 yang dipilih dari 59 orang responden.

Secara garis besar kinerja pelayanan fasilitas parkir kendaraan tunggu yang berada pada total skor sebesar 1.180 atau berada pada katagori Kurang Baik ( 945-1.350).

\section{b. Keamanan}

Tingkat keamanan penumpang pada pelayanan fasilitas parkir Kendaraan Tunggu ditinjau dari 4 indikator yakni keberadaan alat komunikasi dan CCTV, pedestrian pada area parkir, adanya sarana kebakaran,dan cukup penerangan malam hari.

Hasil dari indikator keamanan pada parkir kendaraan tunggu yaitu Sarana pedestrian berada pada tingkat kurang aman (80 \%) dengan bobot 144, dipilih 72 orang responden, dan berikutnya sarana kebakaran pada katagori kurang aman (70 $\%$ ) dengan jumlah skor 126, Secara keseluruhan bahwa kinerja pelayanan fasilitas parkir kendaraan tunggu pada faktor keamanan berada pada total skor sebesar 873 atau berada pada katagori Kurang Baik (630 - 900).

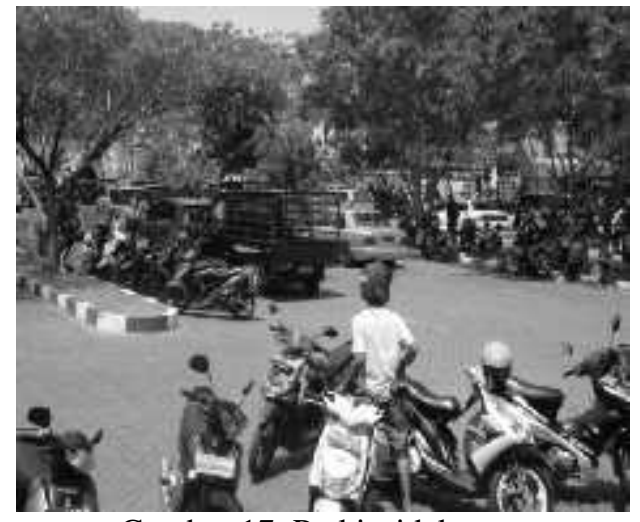

Gambar 17. Parkir tidak teratur

\section{Analisis Kinerja Ruang Tunggu}

a. Kenyamanan

Kenyamanan pada suatu fasilitas Ruang tunggu penumpang menjadi syarat penting, karena ruang sebagai mana fungsinya, tentunya harus dapat menciptakan suasana nyaman, sehingga penumpang merasa betah menunggu keberangkatan kapal di ruang ini.

secara umum hasil dari indikator kenyamanan pada ruang tunggu pada terminal: Bahwa sarana tempat duduk ruang tunggu berada pada tingkat kurang baik ( $66 \%$ ) dengan bobot 118, dipilih 59 orang responden, dan untuk kondisi sarana pendukung (kantin, toilet, mushalla, P3K, ATM, kios Majalah, Tontonan/hiburan TV) berada pada kurang Baik (55 \%) dengan bobot 100 yang dipilih dari 50 orang

responden. Ini berarti bahwa kinerja pelayanan fasilitas ruang tunggu pada indikator kenyamanan berada pada total skor sebesar 831 atau berada pada katagori Kurang Baik ( 630 - 900).

\section{b. Keamanan}

Keamanan pada suatu fasilitas Ruang tunggu penumpang menjadi prioritas sebagai ruang publik , karena area ini harus dapat membuat penumpang merasakan suasana yang aman, memperoleh ketenangan menunggu di ruang ini.

Kelengkapan Sarana penunjang keamanan sangat mempengaruhi pelayanan terhadap penumpang, untuk itu perlu menampung tanggapan penumpang terhadap fasilitas keamanan ruang tunggu. kinerja pelayanan fasilitas ruang tunggu dengan total skor sebesar 659 atau berada pada katagori Kurang Baik (472,5 - 675 ).

\section{Rekapitulasi Kinerja ke 3 prasarana pelabuhan}

Hasil penilaian kinerja terhadap ke tiga fasilitas pelabuhan memperoleh, Total Skor 4.469, ini berarti bahwa kinerja fasilitas pelabuhan Bajoe berada pada katagori Kurang Baik (halaman 71 posisi interval klas $3.465-4.950$ ) 


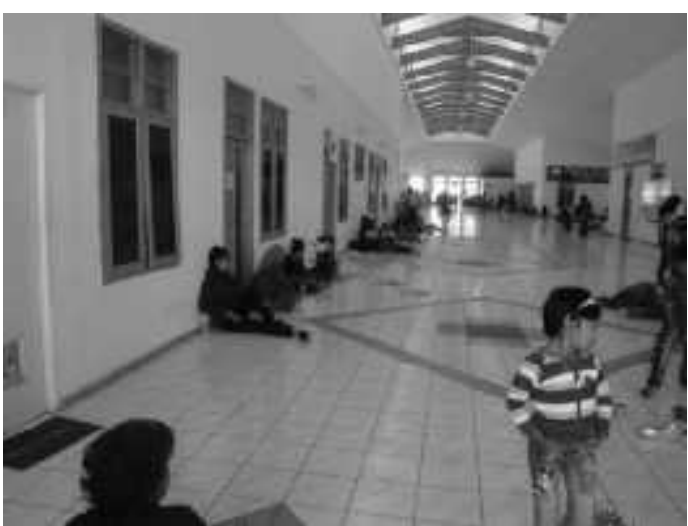

Gambar 18. Ruang Tunggu tanpa sarana tempat duduk (penumpang duduk dan tidur melantai).

\section{PENUTUP}

\section{Kesimpulan}

Berdasarkan pengamatan dan Analisis yang telah dilakukan, maka dapat ditarik kesimpulan bahwa :

1. Penyatuan jalur sirkulasi kendaraan dengan pejalan kaki ke Dermaga dan melewati antrian kendaraan Zona C cukup berpengaruh pada kecepatan pemberangkatan kapal, disebabkan terjadi perlambatan kendaraan naik ke kapal karena pengemudi biasanya memberi kesempatan bagi pejalan kaki menuju kapal.

2. Jarak capai dari pintu gerbang pelabuhan ke Terminal penumpang $\pm 3.000 \mathrm{~m}$ cukup jauh berdasarkan waktu tempuh pejalan kaki mencapai \pm 32- 40 menit dan dengan kendaraan kota (waktu penggantian moda dengan waktu tempuh $\pm 20-25$ menit).

3. Tidak adanya marka/ Pola parkir pada parkir kendaraan tunggu menimbulkan parkir yang semrawut sehingga memperlambat gerak manuver kendaraan menuju Dermaga.

4. Kenyamanan pada parkir tunggu sangat memperihatinkan dengan tidak disiapkan sarana tempat duduk/ istirahat sopir/ pengendara dan penumpang dan demikian juga pada Ruang tunggu penumpang di Terminal.

5. Factor keamanan sangat rendah dengan tidak adanya alat pemadan kebakaran( Fire hydrant dan pemantau keamanan parkir dengan Close CirkuitTelevision (CCTV)

\section{Saran-saran}

1. Pihak Pemerintah Daerah Tingkat II Bone dan pengelola pelabuhan sama -sama memikirkan untuk redesain pencapaian ke Dermaga, dengan membangun infra strutur jalan, guna mendekatkan fasilitas pendukung Pelabuhan seperti pertokoan oleh-oleh perjalanan, rumah makan, penginapan dan fasilitas-fasilitas lainnya seperti pengadaan Bank sebagai tempat pengambilan/ pengiriman uang bagi penumpang. Hal ini tentu akan membuka area ini perkembangan ekonomi yang baru bagi masyarakat sekitar pelabuhan dengan munculnya lapangan kerja dan pusat perdagangan baru.

2. Penyempurnaan jalur sirkulasi ke Dermaga dengan memisahkan/ menyiapkan jalur jalan masing-masing bagi penumpang pejalan kaki dengan penumpang berkendaraan, karena kondisi ini cukup berpengaruh pada kecepatan gerak kendaraan yang tentu berpengaruh pada ketepatan pemberangkatan kapal.

3. Jarak dari pintu gerbang cukup Jauh, dengan memperpendek jangkauan maximal $800 \mathrm{~m}$ sesuai standar kenyamanan pejalan kaki, atau pihak Pengelola Pelabuhan menyiapkan moda angkutan gratis bagi penumpang masuk ke terminal pelabuhan.

4. Segera menyiapan Sarana pendukung khusus pada area parkir kendaraan tunggu, terutama penyiapan tempat istirahat Sopir/Pengemudi, penumpang Bus. tempat ibadah dan ATM.

5. Menyiapkan sarana tempat duduk bagi penumpang pada ruang tunggu penumpang di Terminal.

6. Penyempurnaan pada parkir kendaraan Tunggu dengan penentuan pola parkir dengan marka parkir yang jelas guna mempercepat maneuver kendaraan ke Dermaga.

\section{DAFTAR PUSTAKA}

Ashford, Norman and Wright,1976. Air Port Engineering.

Eryudha Bambang,(2009,55). Busway di Curitiba, Tempo.

Departemen Perhubungan,1989. Fungsi dan Peranan Adpel dalam Memperlancar Arus Barang.

Ferry. http: //en.wikipedia.org, diakses 24 Mar. 2011.

F.D.C. Sudjatmiko, 1985, Pokok-Pokok pelayaran Niaga. Jakarta Akademika Press.

Gultom, Elfrida. 2007. Refungsionalisasi Pengaturan Pelabuhan untuk meningkatkan Ekonomi Nasional. PT Raja Grafindo Persada.

Hakim Rustan dan Utomo Hardi, 2002 . Arsitektur Lansekap. Bumi Aksara.

http;//www.ship.technology.com, Hany, Ahmed Assqol. 2010. Simulasi Sistem Transportasi Kapal Ferry,Studi kasus Pelabuhan Penyeberangan Ketapang-Gilimanuk. Teknik Perkapalan ITS. 
http : //en.wikipwdia.org, Pelabuhan Indonesia II, diakses 21 Maret 2011.

http : //en.wikipwdia.org, Pelabuhan dan Kepelabuhanan,Posted by.Ramadhan's Site.htm. diakses 24 Maret 2011.

http;//www.ship.technology.com, Perencanaan Pembangunan Dermaga Ferry di Nusa Penida.

JINCA, M.Y. 2009, Materi Kuliah, Pengantar Perencanaan Prasarana, TPP Pascasarjana Unhas.

Jinca, M.Y. 2009. Materi Kuliah, Perencanaan Transportasi, TPP Pascasarjana Unhas.

Josep, F.Hair. 1998, Metodologi Penelitian Bisnis, PT Yasa Guna Reksa.

Juwana, Jimmy S. 2005. Panduan Sistem Bangunan Tinggi, Erlangga

Kodoatie,Robert J. 2005. Pengantar Manajemen Infrastruktur. Pustaka Pelajar.

Kosasih, Ongkos, 2007. Manajemen Perusahaan Pelayaran, Suatu Pendekatan Praktis dalam Bidang Usaha Pelayaran. Rajawali Pers.

Kramadibrata,Soedjono, 2002. Perencanaan Pelabuhan. ITB

Lawi, Armin. 2009. Materi Kuliah Statistika dan Metode Penelitian. TPP Pascasarjana Unhas.

Neufert Ernst, Data Arsitektur. Edisi kedua 1998. Erlangga

PPRI No. 61 Tahun 2009. Tentang Kepelabuhanan. 